\title{
Identification of stage-specific changes in protein secretion by isolated seminiferous tubules from rats following exposure to short-term local testicular heating
}

\author{
T. T. McLaren ${ }^{1}$, P. M. D. Foster ${ }^{2}$ and R. M. Sharpe ${ }^{1 *}$ \\ ${ }^{1}$ MRC Reproductive Biology Unit, Centre for Reproductive Biology, 37 Chalmers Street, \\ Edinburgh EH3 9EW, UK; and 'Zeneca, Central Toxicology Laboratory, Alderley Park, \\ Macclesfield SH1O 4TJ, UK
}

\begin{abstract}
The objective of this study was to identify the early (after 4 and $24 \mathrm{~h}$ ) effects of short-term local testicular heating $\left(43^{\circ} \mathrm{C}\right.$ for $\left.30 \mathrm{~min}\right)$ on the secretion of proteins by seminiferous tubules isolated from adult rats at stages II-V, VI-VIII or IX-XII of the spermatogenic cycle, and cultured in vitro for $24 \mathrm{~h}$ with $\left[{ }^{35} \mathrm{~S}\right]$ methionine. Incorporation of $\left[{ }^{35} \mathrm{~S}\right]$ methionine into secreted and intracellular proteins was assessed and the pattern of protein secretion was evaluated using two-dimensional SDS-PAGE. Seminiferous tubules isolated from control rats exhibited the characteristic, androgen-dependent increase in protein secretion at stages VI-VIII. At $4 \mathrm{~h}$ after exposure to local testicular heating, seminiferous tubules at these stages showed a significant increase $(P<0.001)$ in the overall incorporation of $\left[{ }^{35}\right.$ S]methionine into secreted proteins, whereas seminiferous tubules at stages II-V and IX-XII showed no significant change. In marked contrast, seminiferous tubules isolated from rats $24 \mathrm{~h}$ after local testicular heating showed a significant decrease in the incorporation of $\left[{ }^{35}\right.$ S]methionine into secreted proteins at stages VI-VIII $(P<0.001)$ and to a lesser extent at IX-XII $(P<0.05)$, whereas seminiferous tubules at stages II-V showed no change in incorporation. Prior treatment to maintain normal intratesticular concentrations of testosterone in heat-exposed rats failed to prevent these changes. Similar results were obtained when incorporation of $\left[{ }^{35} \mathrm{~S}\right]$ methionine into intracellular proteins was evaluated 4 and $24 \mathrm{~h}$ after exposure to local testicular heating. Analysis of seminiferous tubule-secreted proteins by two-dimensional SDS-PAGE identified three androgen-regulated proteins that showed reproducible decreases in secretion following exposure to local testicular heating. These results suggest that changes in overall protein secretion by seminiferous tubules may explain some of the adverse effects of heat on the testes.
\end{abstract}

\section{Introduction}

The adverse effects of heat on the mammalian seminiferous epithelium are well documented. Early work on natural and experimental cryptorchidism in guinea-pigs and rats (Moore, 1924) and sheep (Moore and Chase, 1923) led to the conclusion that normal spermatogenesis in male mammals with a scrotum requires a temperature lower than body temperature. Quantitative analysis of changes to the seminiferous epithelium of rats exposed to short-term local testicular heating (Chowdhury and Steinberger, 1964, 1970; Bartlett and Sharpe, 1987) have found that, following exposure to temperatures of $43^{\circ} \mathrm{C}$ for 15 or $30 \mathrm{~min}$, primary spermatocytes at stages VII-XII of the spermatogenic cycle are the germ cells most sensitive to damage by heat. The stage specificity of germ-cell degeneration after such treatment could indicate that only selected

* Correspondence.

Received 3 March 1994. interactions between Sertoli cells and germ cells are initially affected by local testicular heating.

It is generally believed that the Sertoli cell plays an important role in the regulation of germ-cell development through a complex series of interactions with the developing germ cells (Jégou and Sharpe, 1993; Sharpe, 1993). It is presumed that these interactions are mediated by the secretion of different proteins by the Sertoli cells and that these vary cyclically according to the stage of the spermatogenic cycle (Parvinen, 1982, 1993). Furthermore, there is increasing evidence to suggest that germ cells can directly modulate the secretory function of the Sertoli cells, according to their own specific requirements (Djakiew and Dym, 1988; Jégou and Sharpe, 1993; Sharpe, 1993). It is presumed that some of these functions are either altered selectively or are more sensitive to the adverse effects of heat. As seminiferous tubules at the various stages of the spermatogenic cycle can be isolated by transillumination-assisted microdissection (Parvinen et al., 
1986), it is potentially possible to identify these alterations in function at the protein level at various time points after heat exposure. Identification of these changes would (i) identify the possible biochemical cause(s) of the adverse effects of heat, (ii) give insight into normal control mechanisms in spermatogenesis and (iii) identify proteins that could be used as early markers of the disruption of spermatogenesis, provided that they are detectable in peripheral blood and that assays can be developed for their measurement (Sharpe, 1992).

The objective of the present study was to take the first steps towards these goals by assessing whether reproducible stagespecific changes in the secretion of proteins could be identified following exposure to heat. Proteins that are secreted from the seminiferous tubules were targeted specifically because it is believed that the secretion of these proteins represents the most important of the possible routes by which Sertoli cells communicate, and thus interact, with the germ cells (Sharpe, 1993).

\section{Materials and Methods}

\section{Animals and treatments}

Young adult Wistar rats approximately 70 days of age and bred in the MRC Reproductive Biology Unit, Edinburgh, were used in studies to identify protein changes associated with heat-induced damage to the testis. They were housed under conventional conditions ( $12 \mathrm{~h}$ light: $12 \mathrm{~h}$ dark) at a temperature of $21^{\circ} \mathrm{C}$ and humidity of $35-60 \%$. Food and water were available ad libitum. Rats were anaesthetized with an i.p. injection of $50 \mathrm{mg}$ sodium pentobarbitone $\mathrm{kg}^{-1}$ (Sagatal: May and Baker Ltd, Dagenham). The lower half of their body, including the scrotum, was then immersed for $30 \mathrm{~min}$ in a thermostatically controlled water bath maintained at $43^{\circ} \mathrm{C}$, while the animals were strapped with velcro ties to a supporting frame. Heat treatment has been shown to cause widespread early germ-cell loss (i.e. of pachytene spermatocytes and early spermatids), although this occurs in a stage-specific and timerelated manner (Bartlett and Sharpe, 1987). Rats were killed 4 or $24 \mathrm{~h}$ after treatment by inhalation of $\mathrm{CO}_{2}$ followed by cervical dislocation and subjected to the procedures described below. As heat treatment was found to have major effects on androgen-dependent protein secretion by seminiferous tubules, two experiments were performed to assess whether testosterone replacement could prevent these changes. Adult rats were injected s.c. with $25 \mathrm{mg}$ testosterone esters (Sustanon: Organon Laboratories, Cambridge, UK) just before they were subjected to local testicular heating as described above; seminiferous tubules were isolated for culture $24 \mathrm{~h}$ later. The dose of testosterone esters administered has been shown to maintain quantitatively normal spermatogenesis for extended periods in rats and to maintain normal intratesticular concentrations of testosterone (Sharpe et al., 1990).

\section{Testicular morphology}

At $24 \mathrm{~h}$ after local testicular heating, three rats were perfusion fixed and results were compared with those from two perfusion-fixed control rats. Buffered 3\% glutaraldehyde was perfused through the rat dorsal aorta using techniques described by Kerr and Sharpe (1985). After post-fixation in $2 \%$ osmium tetroxide, tissue blocks were embedded in EponAraldite (Bio-Rad Laboratories, Hemel Hempstead) and semithin $(1 \mu \mathrm{m})$ sections were cut and stained with Toluidine blue. Cross-sections of seminiferous tubules were examined using a Zeiss photomicroscope and classified into stages as described by Leblond and Clermont (1952).

\section{Isolation and culture of seminiferous tubules}

Seminiferous tubules were isolated and cultured using slight modifications of the method of Allenby et al. (1991a, b). Testes were kept on ice, decapsulated within $2 \mathrm{~h}$ of removal from the animal and placed into a small plastic Petri dish containing ice-cold Dulbecco's PBS on a cooled $\left(4^{\circ} \mathrm{C}\right)$ transparent Perspex stage illuminated from below. Lengths of seminiferous tubules were then isolated by gently teasing apart the central portion of the testis using fine watchmakers' forceps. Tubules were isolated in sections of $>2 \mathrm{~cm}$ (approximate range $2-5 \mathrm{~cm}$ ).

Isolated tubules were transferred to a separate Petri dish containing fresh PBS and dissected into stages II-V, VI-VIII or IX-XII of the spermatogenic cycle, according to the criteria of Parvinen (1982). The selection of stage groupings was based on both the ease with which particular stages can be distinguished from one another and on the stage specificity of the early adverse effects of local testicular heating on spermatogenesis in vivo (Bartlett et al., 1987). Seminiferous tubules were cut using a scalpel and only those seminiferous tubules $>0.5 \mathrm{~cm}$ in length were used. Seminiferous tubules that showed signs of damage or stretching were excluded. Staged seminiferous tubules were transferred subsequently to fresh PBS and, by reference to a transparent grid, a total length of seminiferous tubules of $10 \mathrm{~cm}$ at each stage grouping was transferred to a 24-well plastic culture plate containing $0.1 \mathrm{ml}$ culture medium; this consisted of Eagle's minimal essential medium without methionine (Flow Laboratories, Irvine, CA) containing $4 \mathrm{mmol}$ L-glutamine $1^{-1}$ (Sigma Chemical Co., Poole), $100 \mu \mathrm{U}$ penicillin $\mathrm{ml}^{-1}, 100 \mu \mathrm{g}$ streptomycin $\mathrm{ml}^{-1}$ (Flow Laboratories), $25 \mathrm{mmol}$ Hepes $\mathrm{l}^{-1}$ (Gibco, Paisley) and $0.1 \%(\mathrm{v} / \mathrm{v})$ polyvinyl alcohol (Sigma Chemical Co.) per well as a protein substitute (Sharpe et al., 1992). Immediately before incubation, $60 \mu \mathrm{Ci}\left[{ }^{35} \mathrm{~S}\right]$ methionine (specific activity, $>1000 \mathrm{Ci}$ $\mathrm{mmol}^{-1}$; ICN Flow, High Wycombe) was added to each culture. Seminiferous tubules were cultured for $24 \mathrm{~h}$ at $32^{\circ} \mathrm{C}$ under a humidified atmosphere of $5 \% \mathrm{CO}_{2}$ and $95 \%$ air. Each set of seminiferous tubules of total length $10 \mathrm{~cm}$ was incubated in a final volume of $0.4 \mathrm{ml}$. At the end of the incubation period, the medium was aspirated from the seminiferous tubules into an Eppendorf tube containing a protease inhibitor (Aprotinin at a final concentration of $5 \% \mathrm{v} / \mathrm{v}$; Sigma Chemical Co.). The medium was then centrifuged at $1000 \mathrm{~g}$ for $5 \mathrm{~min}$ and the aspirate stored at $-40^{\circ} \mathrm{C}$. Incorporation of $\left[{ }^{35} \mathrm{~S}\right]$ methionine into secreted proteins (in the aspirated culture medium) and lysates was assessed after precipitation with trichloroacetic acid and scintillation counting. All experiments were repeated two to four times. 


\section{Two-dimensional SDS-PAGE}

A water-cooled Protean II electrophoresis system and a model 3000xi power supply from Bio-Rad Laboratories were used in all the procedures. The method used was described by Sharpe et al. (1992). Tube gels for isoelectric focusing consisted of $5.5 \mathrm{~g}$ urea (Sigma Chemical Co.), $1.33 \mathrm{ml}$ pre-mixed $30 \%$ $\mathrm{w} / \mathrm{v}$ acrylamide/bis (Bio-Rad Laboratories), $2 \mathrm{ml} 10 \%$ nonidet P-40 (BDH), $0.6 \mathrm{ml}$ ampholines $(0.4 \mathrm{ml}, \mathrm{pH} 5-7 ; 0.15 \mathrm{ml}$ $\mathrm{pH} 7-9 ; 0.05 \mathrm{ml}, \mathrm{pH} 3-10)$ (Bio-Rad Laboratories) and $2.15 \mathrm{ml}$ deionized, distilled water (DD water). After degassing the monomer solution for $2 \mathrm{~min}$, polymerization was initiated by adding $20 \mu \mathrm{l}$ fresh $10 \% \mathrm{w} / \mathrm{v}$ ammonium persulfate and $10 \mu \mathrm{l}$ TEMED (both from Sigma Chemical Co.). Isoelectric focusing gels were poured to a height of $11 \mathrm{~cm}$ in glass capillary tubes $160 \mathrm{~mm}$ high and with an internal diameter of $2.5 \mathrm{~mm}$ (Bio-Rad Laboratories). Gels were then overlaid with $50 \mu \mathrm{IDD}$ water until polymerized $(2 \mathrm{~h})$. At this time the overlay was replaced with $20 \mathrm{mmol} \mathrm{NaOH} 1^{-1}$ and further polymerized for $1 \mathrm{~h}$. The gels were then prefocused at $200 \mathrm{~V}$ for $15 \mathrm{~min}, 300 \mathrm{~V}$ for $30 \mathrm{~min}$, and $400 \mathrm{~V}$ for $15 \mathrm{~min}$, using $6 \mathrm{mmol}$ phosphoric acid $1^{-1}$ as the anolyte and freshly degassed $20 \mathrm{mmol} \mathrm{NaOH}^{-1}$ as the catholyte.

Seminiferous-tubule-conditioned medium was mixed with an equal volume of isoelectric focusing sample buffer $(9.5 \mathrm{~mol}$ urea $1^{-1}, 2 \% \mathrm{v} / \mathrm{v}$ nonidet P-40, $2 \% \mathrm{w} / \mathrm{v}$ ampholines and $1 \% \mathrm{w} / \mathrm{v}$ dithiothreitol) and additional urea was added to ensure a final concentration of $9.5 \mathrm{~mol} \mathrm{l}^{-1}$. The samples were incubated at room temperature for $15 \mathrm{~min}$ before they were centrifuged at $1000 \mathrm{~g}$ for $3 \mathrm{~min}$. Each tube gel was loaded with equal amounts of $\left[{ }^{35}\right.$ S $]$ methionine-labelled proteins $\left(200-250 \times 10^{3}\right.$ c.p.m. $)$. Blank tube gels were loaded with $50 \mu \mathrm{l}$ isoelectric focusing sample buffer. Gels were then prefocused at $400 \mathrm{~V}$ for $14 \mathrm{~h}$, followed by $800 \mathrm{~V}$ for $2 \mathrm{~h}$. Sample gels were then extruded, placed into a storage tube containing $0.5 \mathrm{ml}$ sample buffer [made up of $10 \mathrm{ml} 0.5 \mathrm{~mol}$ Tris $-\mathrm{HCl} \mathrm{1}{ }^{-1}, \mathrm{pH} 6.8,20 \mathrm{ml} 10 \%$ SDS, $4 \mathrm{ml} 0.05 \% \mathrm{w} / \mathrm{v}$ bromophenol blue (Bio-Rad Laboratories) and $36 \mathrm{ml} \mathrm{DD}$ water], incubated at room temperature for $3 \mathrm{~min}$ before being frozen rapidly in ethanol:dry ice, and stored at $-40^{\circ} \mathrm{C}$. Blank tube gels were then sectioned into $5 \mathrm{~mm}$ segments, placed into $1.4 \mathrm{ml} \mathrm{DD}$ water, and allowed to stand at room temperature for $4-6 \mathrm{~h}$, before measurement of $\mathrm{pH}$.

Slab gels that contained $10 \% \mathrm{w} / \mathrm{v}$ acrylamide were used for the second dimension of gel electrophoresis. Each of these gels consisted of $13.3 \mathrm{ml}$ acrylamide in $10 \mathrm{ml} 1.5 \mathrm{~mol}$ Tris- $-\mathrm{HCl}^{-1}$ (pH 8.8) and $16.7 \mathrm{ml} \mathrm{DD}$ water. After degassing for $15 \mathrm{~min}$, polymerization was initiated by adding $600 \mu \mathrm{l}$ fresh $10 \% \mathrm{w} / \mathrm{v}$ ammonium persulfate and $18 \mu \mathrm{l}$ TEMED. Gels were overlaid with water-saturated iso-butanol (Aldrich Chemical Co., Gillingham) for approximately $\mathrm{I} h$, washed with $\mathrm{DD}$ water and then overlaid with $0.375 \mathrm{~mol}$ Tris- $\mathrm{HCl} 1^{-1}$ (pH 8.8) until required. Frozen isoelectric focusing gels were thawed at room temperature and then transferred carefully to the top of the slab gel to ensure that no air bubbles were trapped; no sealing medium was used. The electrolyte buffer used contained $0.3 \%$ $\mathrm{w} / \mathrm{v}$ Tris base, $1.44 \%$ glycine and $0.1 \%$ SDS (all from Sigma Chemical Co.) in DD water. Gels were run at $38 \mathrm{~mA}$ per gel for approximately $2 \mathrm{~h}$, fixed for $30 \mathrm{~min}$ in methanol:acetic acid:DD water (40:10:10; v:v:v) and then silver stained using a kit from Bio-Rad Laboratories. The gels were then soaked for $15 \mathrm{~min}$ in
Amplify (Amersham International, Amersham) and dried under vacuum for $2 \mathrm{~h}$ at $62^{\circ} \mathrm{C}$ before being exposed to $\mathrm{X}$-ray film (Kodak X-OMAT ARS) at $-80^{\circ} \mathrm{C}$ for 21 days.

\section{Statistical analysis}

Differences between groups were analysed by analysis of variance and Student's $t$ test.

\section{Results}

\section{Effect of local testicular heating on testicular morphology}

In rats exposed to $43^{\circ} \mathrm{C}$ for $30 \mathrm{~min}$, examination of sections from perfusion-fixed testes (Fig. 1) confirmed in general the detailed analyses of Chowdhury and Steinberger $(1964,1970)$. In such testes, widespread but stage-specific (stages II-XIV) damage or loss of pachytene spermatocytes was the most obvious change. Interestingly, the heads of step 19 spermatids were found to be embedded deeply in the Sertoli cell cytoplasm at stages VI-VIII rather than in their normal position of being grouped around the edge of the tubule lumen (Fig. 1a, b). Extensive vacuolation of the seminiferous epithelium, at the level of the tight junctions, of many tubules was also evident (Fig. 1b, c), and retention of sperm heads was a prominent feature of tubules at stages IX-XIV (Fig. Id). Round spermatids at stages I-VIII were seen more frequently compared with controls. Apart from the widespread loss of pachytene spermatocytes, tubules at stages I-V were relatively unaffected by local testicular heating $24 \mathrm{~h}$ earlier, especially when compared with tubules at stages VII-XII.

\section{Effect of local testicular heating on testicular mass}

The mean testicular mass was reduced significantly $(P<0.001) 24 \mathrm{~h}$ after local testicular heating to $1587 \pm 121 \mathrm{mg}$ (mean $\pm \mathrm{SD}, n=5$ ) but not $4 \mathrm{~h}$ after treatment $(1873 \pm 91 \mathrm{mg}$ ) when compared with controls (1878 $\pm 101 \mathrm{mg})$.

\section{Stage-dependent differences in overall protein secretion}

The overall incorporation of $\left.{ }^{35} \mathrm{~S}\right]$ methionine into proteins secreted into the incubation medium by seminiferous tubules at stages VI-VIII from control rats was approximately double that at stages II-V or IX-XIII, whereas incorporation into intracellular proteins showed no such difference between the stages (Figs 2 and 3). This difference was evident in the control group in each of the experiments in this study.

\section{Effect of local testicular heating on overall protein secretion}

After short-term local testicular heating, there was a significant increase $(P<0.001)$ in the incorporation of $\left[{ }^{35} S\right]$ methionine into newly synthesized proteins secreted into the incubation medium by seminiferous tubules at stages VI-VIII when isolated $4 \mathrm{~h}$ after treatment; seminiferous tubules at stages II-V or IX-XII showed no significant change in incorporation when compared with controls (Fig. 2a). In 

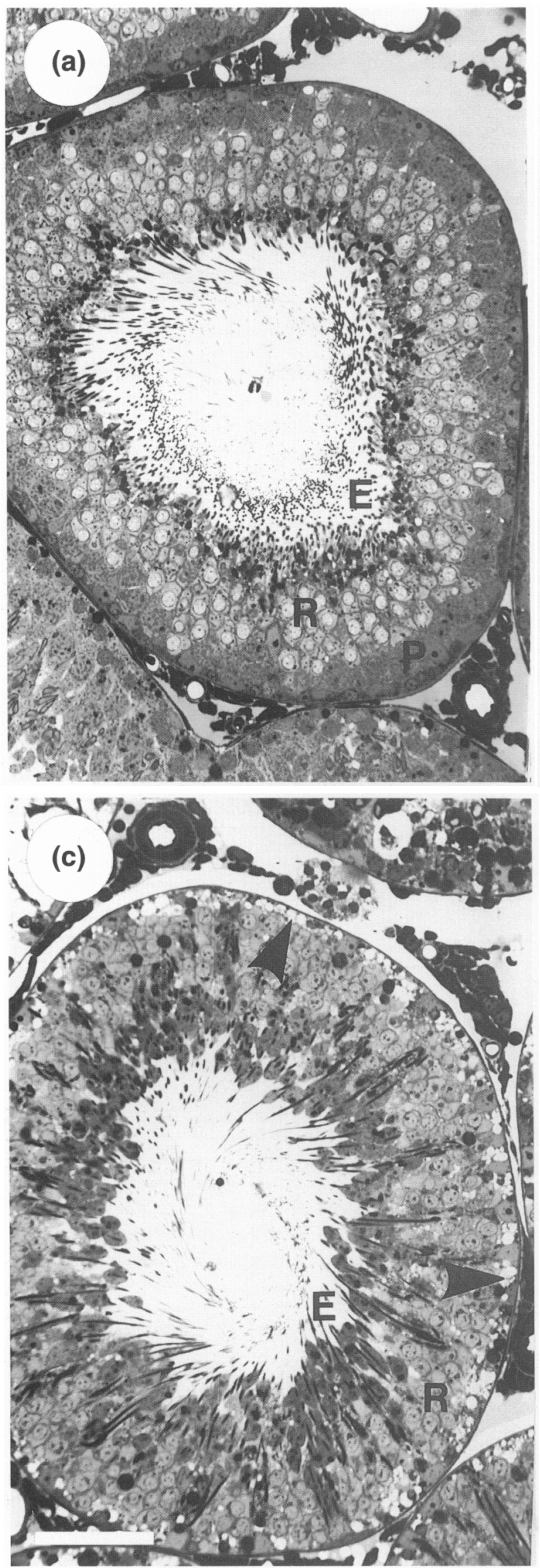

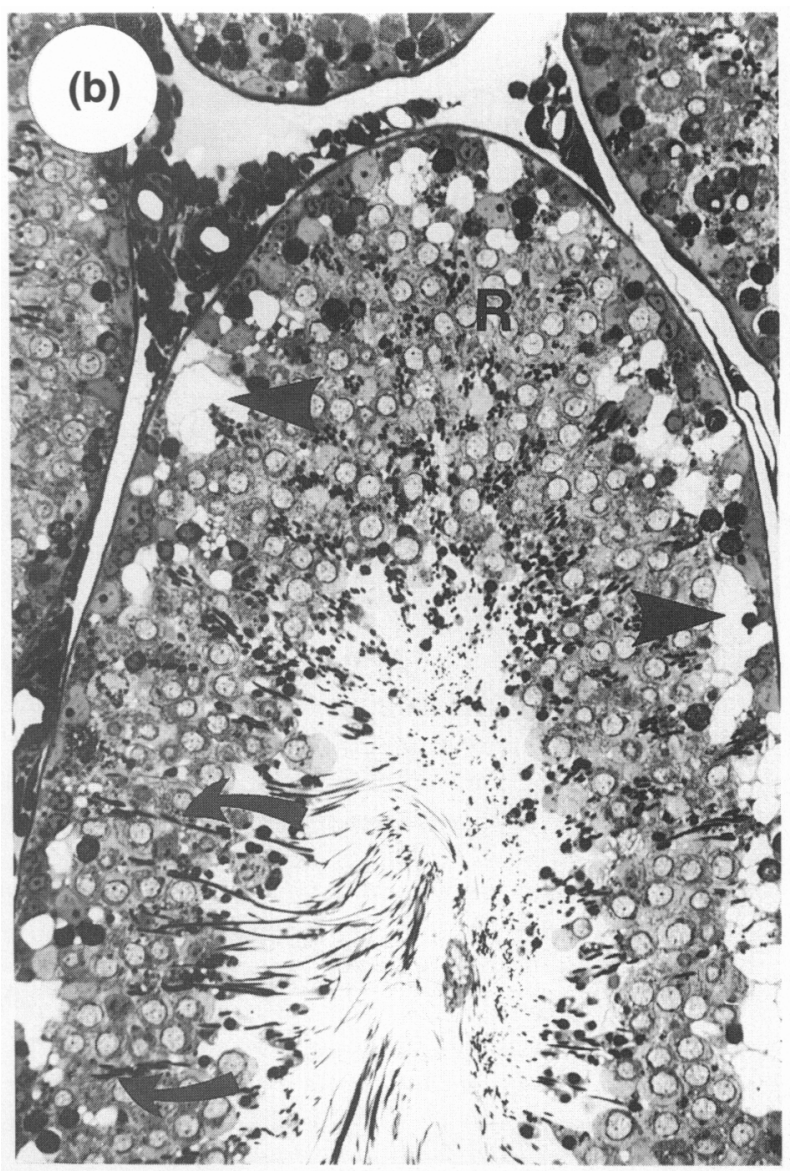

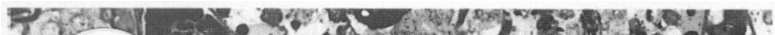

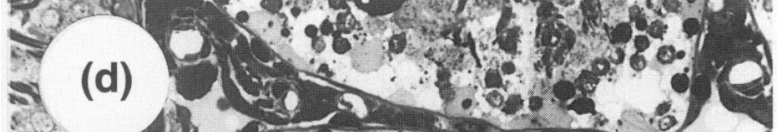

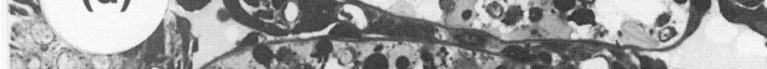

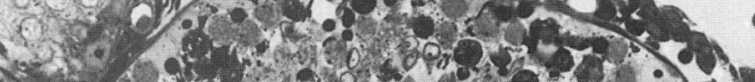

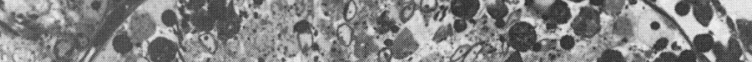

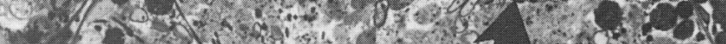

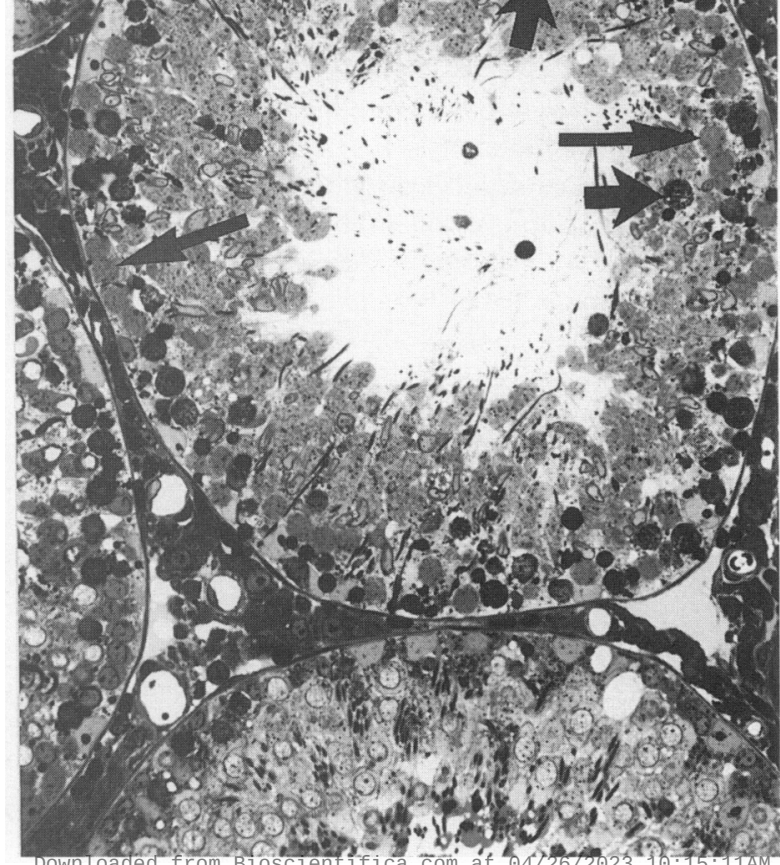




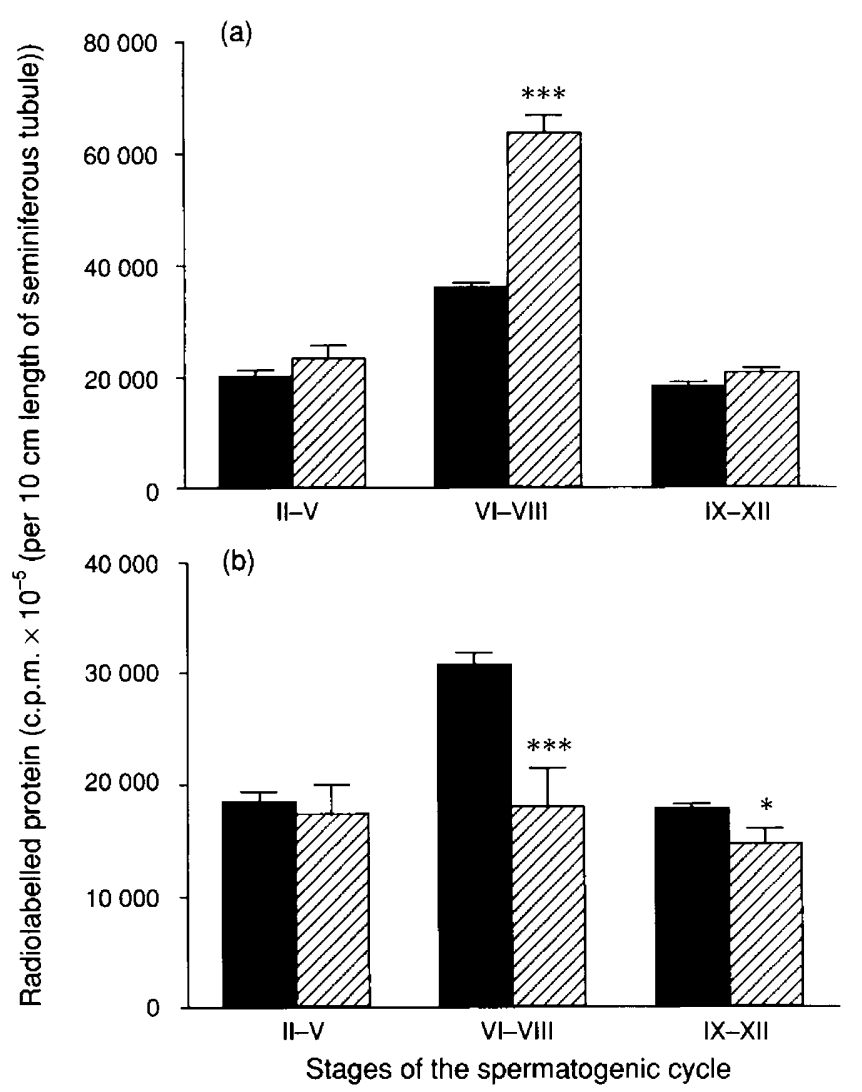

Fig. 2. Incorporation of $\left[{ }^{35} \mathrm{~S}\right]$ methionine over $24 \mathrm{~h}$ into newly synthesized proteins secreted in vitro by seminiferous tubules isolated at different stages of the spermatogenic cycle from control rats ( $\boldsymbol{\square})$ or rats that had been exposed to short-term local testicular heating $\left(43^{\circ} \mathrm{C}\right.$ for $30 \mathrm{~min}$ ) ( $\square$ ) either (a) 4 or (b) $24 \mathrm{~h}$ earlier, and cultured for $24 \mathrm{~h}$. Values are means $\pm S D ; n=4 .{ }^{*} P<0.05 ;{ }^{* * *} P<0.001$ compared with the respective control group.

contrast, seminiferous tubules isolated from rats $24 \mathrm{~h}$ after heat treatment showed a marked decrease in incorporation of radioactivity into secreted proteins at stages VI-VIII $(P<0.001)$ and a small decrease at stages IX-XII $(P<0.05$; Fig. $2 b)$, whereas seminiferous tubules at stages II-V showed no change in incorporation at this time. This heat-induced decrease in the concentration of secreted protein by seminiferous tubules at stages VI-VIII $24 \mathrm{~h}$ after treatment effectively abolished the normal, androgen-dependent increase in protein secretion observed at these stages.
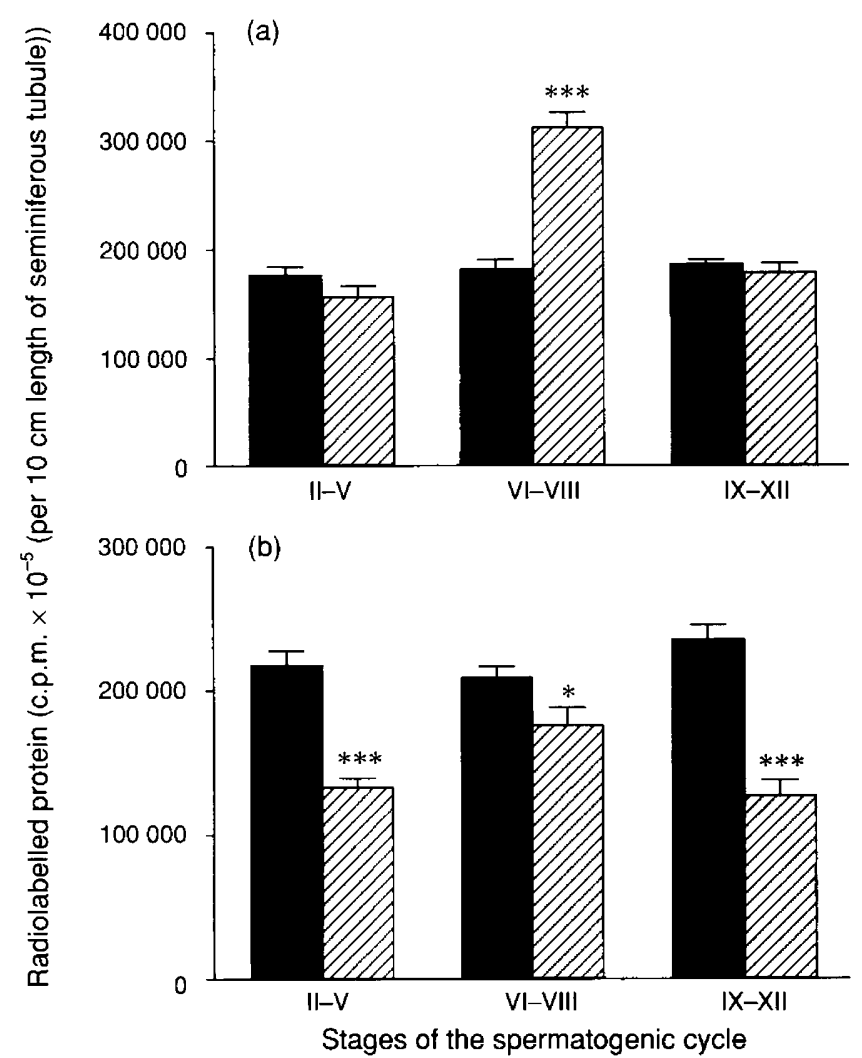

Fig. 3. Incorporation of $\left[{ }^{35} \mathrm{~S}\right]$ methionine into newly synthesized intracellular proteins by seminiferous tubules isolated at different stages of the spermatogenic cycle from control rats $(\boldsymbol{a})$ or rats that had been exposed to short-term local testicular heating $\left(43^{\circ} \mathrm{C}\right.$ for $30 \mathrm{~min}$ ) ( $(\because)$ either (a) 4 or (b) $24 \mathrm{~h}$ earlier, and cultured for $24 \mathrm{~h}$. Values are means $\pm \mathrm{SD} ; n=4$. ${ }^{*} P<0.05 ;{ }^{* * *} P<0.001$ compared with the respective control group.

\section{Effect of local testicular heating on synthesis of intracellular} proteins

After short-term local testicular heating, the pattern of change in the synthesis of intracellular radiolabelled proteins was comparable to that for secreted proteins. Thus, $4 \mathrm{~h}$ after heat treatment there was a significant increase $(P<0.001)$ in the incorporation of $\left[{ }^{35} \mathrm{~S}\right]$ methionine into intracellular proteins in seminiferous tubules at stages VI-VIII, whereas seminiferous tubules at stages II-V or IX-XII showed no significant change

Fig. 1. Effect of local testicular heating $24 \mathrm{~h}$ earlier on the cross-sectional morphology of rat seminiferous tubules at different stages of the spermatogenic cycle. (a) Stage VII in a control rat, exhibiting a full complement of germ cells. (b) Stage VII (based on the acrosomal development of round spermatids) in a rat exposed to local testicular heating. Note the complete absence of pachytene spermatocytes but the near-normal complement of other germ types. Note, however, the markedly abnormal position of the step 19 spermatids (curved arrows), which are embedded deep within the epithelium instead of grouped around the edge of the lumen as in a normal tubule at stage VII (see (a)). Note also the abnormal vacuolation (arrowheads) towards the base of the seminiferous epithelium. (c) Stage III in a rat exposed to local testicular heating. Note the complete absence of pachytene spermatocytes but the near-normal complement of other germ cell types. Note also the abnormal vacuolation (arrowheads) towards the base of the seminiferous epithelium. (d) Stage $X$ in a rat exposed to local testicular heating. Note that pachytene spermatocytes are absent or degenerative (short arrows), whereas zygotene spermatocytes (long arrows) appear normal. Other abnormalities include retained sperm heads and reduced numbers of condensing spermatids. E: elongate spermatids; P: pachytene spermatocytes; R: round spermatids. Scale bar represents $100 \mu \mathrm{m}$. 
(a)

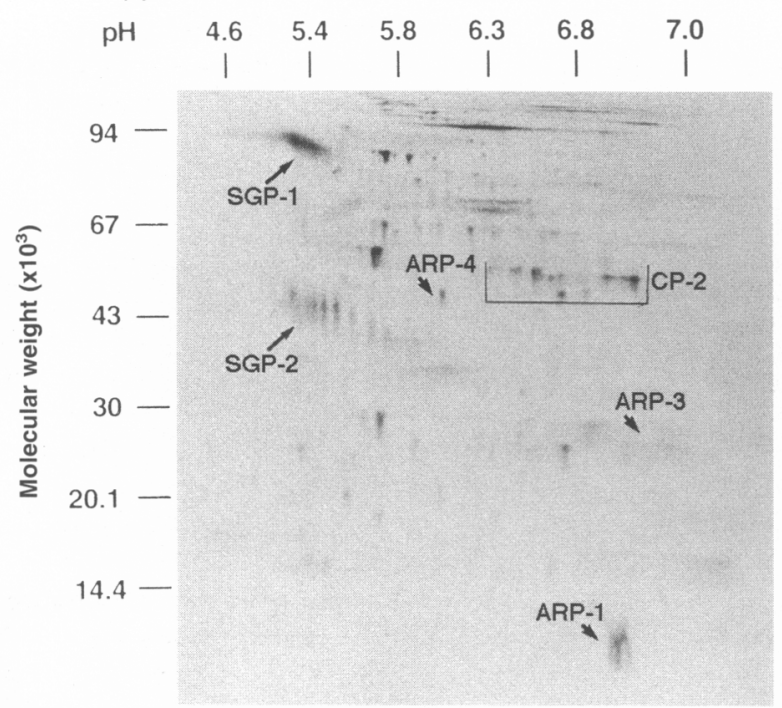

(b)

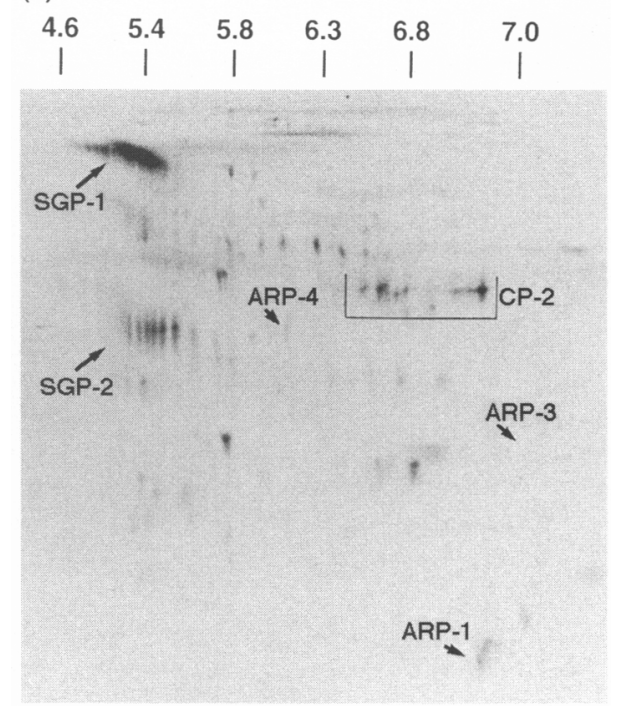

Fig. 4. Analysis by two-dimensional SDS-PAGE of radiolabelled proteins secreted in vitro by seminiferous tubules isolated at stages VI-VIII from (a) control rats or (b) rats that had been exposed to short-term local testicular heating $\left(43^{\circ} \mathrm{C}\right.$ for $\left.30 \mathrm{~min}\right) 24 \mathrm{~h}$ earlier and then cultured for $24 \mathrm{~h}$. Previously identified androgen-regulated proteins (ARPs) which decreased in relative abundance following local testicular heating are labelled ARP-1, ARP-3 and ARP-4. The positions of the three major Sertoli-cell-secreted proteins, sulfated glycoprotein-1 (SGP-1), sulfated glycoprotein-2 (SGP-2) and cyclic protein-2 (CP-2), are indicated for reference. Both gels were loaded with equal amounts of $\left.{ }^{35} \mathrm{~S}\right]$ methionine-labelled protein.

in incorporation when compared with controls (Fig. 3a). By $24 \mathrm{~h}$ after treatment the incorporation of radiolabel into intracellular proteins was decreased in seminiferous tubules at stages II-V, VI-VIII and IX-XII (Fig. 3), although the decrease at stages VI-VIII was not as marked as for secreted proteins (Figs 2 and 3).

\section{Effect of testosterone administration to heat-treated rats}

The maintenance of normal intratesticular concentrations of testosterone by injecting $25 \mathrm{mg}$ testosterone esters failed to alter the decrease in the overall secretion of radiolabelled protein by seminiferous tubules at stages VI-VIII, induced by heat treatment $24 \mathrm{~h}$ earlier [mean ( $\pm \mathrm{SD}$ ) control value: $28562 \pm 895 \times 10^{5}$ c.p.m. per $10 \mathrm{~cm}$ length of seminiferous tubule $(n=3)$; mean ( $\pm \mathrm{SD})$ heat-treated value: $12911 \pm 1426$ $(n=3)$; mean $( \pm \mathrm{sD})$ heat- plus testosterone-ester-treated value: $12297 \pm 1455(n=3)]$.

\section{Two-dimensional SDS-PAGE}

As the effect of local testicular heating had the most marked effect on overall protein secretion at stages VI-VIII, newly synthesized proteins secreted at these same stages, from control and heat-treated rats, were analysed by twodimensional SDS-PAGE (Fig. 4). After heat treatment $4 \mathrm{~h}$ earlier, no major changes in the secretion of specific proteins were observed (data not shown). However, by $24 \mathrm{~h}$ after treatment, three previously identified androgen-regulated proteins (ARP-I, ARP-3 and ARP-4) (Sharpe et al., 1992) showed a pronounced and repeatable decrease in relative abundance.

\section{Discussion}

The objective of the present study was to identify early changes in protein secretion by seminiferous tubules following disruption of spermatogenesis induced by short-term local testicular heating. Unexpectedly, the results have shown that this treatment has major effects on the androgendependent increase in the overall secretion of protein by seminiferous tubules at stages VI-VIII. Changes in the secretion of three specific proteins that have been shown to be androgen-dependent were also identified. These findings also shed light on the mechanism of testicular damage induced by heat.

The present study has confirmed that local testicular heating causes damage to spermatogenesis that is both stage- and cell-specific (Chowdhury and Steinberger, 1964, 1970; Collins and Lacy, 1969), and that spermatocytes are most affected. The present study has also shown for the first time that exposure to short-term local testicular heating $\left(43^{\circ} \mathrm{C}\right)$ for $30 \mathrm{~min}$ (Bartlett and Sharpe, 1987) results in stage-specific changes in the overall incorporation of $\left[{ }^{35} \mathrm{~S}\right]$ methionine into both secreted and intracellular proteins by seminiferous tubules isolated 4 and $24 \mathrm{~h}$ after treatment. The most striking of these changes is the effect of local testicular heating on the overall amount of secretion of radiolabelled proteins by seminiferous tubules at stages VI-VIII. Previous studies have shown that protein secretion at these stages is approximately double that of seminiferous tubules at other stages, an increase that is totally androgen dependent (Sharpe et al., 1992, 1993; McKinnell and Sharpe, 1992). The present findings show that, within $4 \mathrm{~h}$ of local testicular heating, this stage-dependent increase in protein secretion is exacerbated, whereas by $24 \mathrm{~h}$ it is abolished 
completely; at the same time, changes in protein secretion by tubules at stages II-V and IX-XII were either not evident or were minor in comparison with those observed at stages VI-VIII. This heat-induced perturbation of protein secretion by tubules at stages VI-VIII is unlikely to be related to alterations in testosterone concentrations for the following reasons. First, previous studies have shown that intratesticular testosterone concentrations are not reduced by local testicular heating (Bartlett and Sharpe, 1987) and that after complete withdrawal of testosterone it takes $72 \mathrm{~h}$ to reduce protein secretion by tubules at stages VI-VIII (Sharpe et al., 1992). Second, in the present study it was shown that administering a dose of testosterone esters known to maintain quantitatively normal spermatogenesis and fertility in rats (Sharpe et al., 1990) completely failed to alter the deleterious effects of heat treatment $24 \mathrm{~h}$ earlier on protein secretion by seminiferous tubules at stages VI-VIII.

This study also showed that local testicular heating altered the incorporation of $\left[{ }^{35} \mathrm{~S}\right]$ methionine into intracellular proteins at stages VI-VIII in a comparable manner to that of secreted proteins. This may indicate an alteration in one or more basic aspects of metabolic activity in tubules at these stages. These changes may explain some of the adverse effects of heat on spermatogenesis. It is also noteworthy that within $24 \mathrm{~h}$ of treatment of rats with testicular toxicants at doses known to cause subsequent disruption of spermatogenesis, precisely the same changes are observed to those shown to occur at $24 \mathrm{~h}$ after local testicular heating (McLaren et al., 1993); that is, the normal stage-dependent increase in protein secretion at stages VI-VIII fails to occur, despite the maintenance of normal concentrations of testosterone.

Despite a significant increase in the overall incorporation of $\left[{ }^{35} \mathrm{~S}\right]$ methionine into secreted proteins by seminiferous tubules isolated at stages VI-VIII $4 \mathrm{~h}$ after local testicular heating, analysis by two-dimensional SDS-PAGE revealed that no major changes had occurred in the secretion of specific proteins. However, by $24 \mathrm{~h}$ after local testicular heating, the secretion of three androgen-regulated proteins was found to have changed. Furthermore, the secretion of these three proteins has been shown to be affected adversely following exposure to testicular toxicants (McLaren et al., 1993). These earlier findings and those from the present study thus suggest that disruption of spermatogenesis by various agents may involve common pathways. Moreover, these pathways may involve downstream events of androgen action on the seminiferous tubule.

In this study, the morphological effects of local heating on the rat testis were identified histologically within $24 \mathrm{~h}$ of treatment. These initial effects were manifest as the loss or degeneration of pachytene spermatocytes at all stages of the spermatogenic cycle, while the nuclei of elongate spermatids at stages VI-VIII were found to be embedded deep within the cytoplasm of Sertoli cells. Round spermatids in stages I-VII appeared normal, compared with controls. The reason for the initial susceptibility of pachytene spermatocytes to the adverse effects of local testicular heating is unknown. However, treatment of rats with chemicals such as $m$-dinitrobenzene (Blackburn et al., 1988), nitrobenzene (Bond et al., 1981), ethylene glycol monomethyl ether/methoxyacetic acid (Chapin et al., 1984; Creasy et al., 1985) and an imidazole compound
(De Martino et al., 1975) have all been shown to cause rapid degeneration of pachytene spermatocytes.

As specific depletion of pachytene spermatocytes from seminiferous tubules at stages VI-VIII also considerably reduces the amount of protein secreted at stages VI-VIII (McKinnell and Sharpe, 1992; Sharpe et al., 1993), it is possible that it is the loss of these cells induced by heat tratment that is responsible for the alterations in seminiferous tubule protein secretion. However, the pattern of change in androgenregulated proteins induced by heat treatment is substantially different from that induced by depletion of pachytene spermatocytes (McKinnell and Sharpe, 1992). In addition, depletion of pachytene spermatocytes has no effect on the incorporation of $\left[{ }^{35}\right.$ S]methionine into intracellular proteins at stages VI-VIII (C. McKinnell and R. Sharpe, unpublished), whereas heat treatment $24 \mathrm{~h}$ earlier caused a reduction.

In conclusion, the present study has shown that exposure to short-term local testicular heating causes stage-specific changes in the incorporation of $\left[{ }^{35}\right.$ S $]$ methionine into both secreted and intracellular proteins, changes that particularly affect androgendependent aspects of seminiferous tubule function and which may be an important cause of the disruption of spermatogenesis following heat treatment.

\section{References}

Allenby G, Foster PMD and Sharpe RM (1991a) Evidence that secretion of immunoactive inhibin by seminiferous tubules from the adult rat testis is regulated by specific germ cell types: correlation between in-vivo and in-vitro studies Endocrinology 128 467-476

Allenby G, Foster PMD and Sharpe RM (1991b) Evaluation of changes in the secretion of immunoactive inhibin by adult rat seminiferous tubules in-vitro as an indicator of early toxicant action on spermatogenesis Fundamental and Applied Toxicology $16710-724$

Bartlett JMS and Sharpe RM (1987) Effect of local heating of the rat testis on the levels in interstitial fluid of a putative paracrine regulator of the Leydig cells and its relationship to changes in Sertoli cell secretory function Journal of Reproduction and Fertility 80 279-287

Blackburn DM, Gray AJ, Lloyd SC, Sheard CM and Foster PMD (1988) A comparison of the effects of the three isomers of DNB on the testis in the rat Toxicology and Applied Pharmacology 92 54-64

Bond JA, Chism JP, Rickert DE and Popp JA (1981) Induction of hepatic and testicular lesions in Fisher-344 rats by single oral doses of nitrobenzene Fundamental and Applied Toxicology $1389-394$

Chapin RE, Dutton SL, Ross MD, Sumrell BM and Lamb JC (1984) The effects of ethylene glycol monomethyl ether on testicular histology in F344 rats Journal of Andrology 5 369-380

Chowdhury AK and Steinberger E (1964) A quantitative study of the effect of heat on germinal epithelium of rat testes American Journal of Anatomy 115 $509-524$

Chowdhury AK and Steinberger E (1970) Early changes in the germinal epithelium of rat testes following exposure to heat Journal of Reproduction and Fertility 22 205-212

Collins P and Lacy D (1969) Studies on the structure and function of the mammalian testis. II. Cytological and histochemical observations on the testis of the rat after a single exposure to heat applied for different lengths of time Proceedings of the Royal Society of London Series B 172 17-38

Creasy DM, Flynn JC, Gray TJB and Butler WH (1985) A quantitative study of stage-specific spermatocyte damage following administration of ethylene glycol monomethyl ether in the rat Experimental and Molecular Pathology $\mathbf{4 3}$ 321-326

De Martino D, Stefanini M, Agrestini A, Cocchia D, Morelli M and Barcellona PS (I975) Antispermatogenic activity of 1-p. chlorobenzyl-IH indazol-3carboxylic acid (AF 1312/TS) in rats, III. A light and electron microscopic study after single oral doses Experimental and Molecular Pathology 23 $321-356$ 
Djakiew D and Dym MD (1988) Pachytene spermatocyte proteins influence Sertoli cell function Biology of Reproduction 39 1193-1205

Jégou B and Sharpe RM (1993) Paracrine mechanisms in testicular control. In Molecular Biology of the Male Reproductive System pp 271-310 Ed. DM de Kretser. Academic Press, New York

Kerr JB and Sharpe RM (1985) Follicle-stimulating hormone induction of Leydig cell maturation Endocrinology 116 2592-2604

Leblond CP and Clermont Y (1952) Definition of the stages of the cycle of the seminiferous epithelium in the rat Annals of the New York Academy of Sciences 55 548-573

McKinnell C and Sharpe RM (1992) The role of specific germ cell types in modulation of the secretion of androgen-regulated proteins (ARPs) by stage VI-VIII seminiferous tubules from the adult rat Molecular and Cellular Endocrinology 83 219-231

McLaren TT, Foster PMD and Sharpe RM (1993) Identification of stage-specific changes in protein secretion by isolated seminiferous tubules from the rat following exposure to either $m$-dinitrobenzene or nitrobenzene Fundamental and Applied Toxicology 21 384-392

Moore CR (1924) Heat application and testicular degeneration: the function of the scrotum American Journal of Anatomy 34 337-358

Moore CR and Chase HD (1923) Heat application and testicular degeneration Anatomical Record 26 344-345

Parvinen M (1982) Regulation of the seminiferous epithelium Endocrine Reviews $3404-417$
Parvinen M (1993) Cyclic function of the Sertoli cells. In The Sertoli Cell pp 314-347 Eds LD Russell and MD Griswold. Cache River Press, Clearwater, FL

Parvinen M, Vihko KK and Toppari J (1986) Cell interactions during the seminiferous epithelial cycle International Review of Cytology 104 $115-129$

Sharpe RM (1992) Monitoring of spermatogenesis in man-measurement of Sertoli cell- or germ cell-secreted proteins in semen or blood International Journal of Andrology 15 201-210

Sharpe RM (1993) Experimental evidence for Sertoli-germ cell and SertoliLeydig cell interactions. In The Sertoli Cell pp 391-419 Eds LD Russell and MD Griswold. Cache River Press, Clearwater, FL

Sharpe RM, Maddocks S and Kerr JB (1990) Cell-cell interactions in the control of spermatogenesis as studied using Leydig cell destruction and testosterone replacement American Journal of Anatomy 188 3-20

Sharpe RM, Maddocks S, Millar M, Saunders PTK, Kerr JB and McKinnell C (1992) Testosterone and spermatogenesis: identification of stage-dependent, androgen-regulated proteins secreted by adult rat seminiferous tubules Journal of Andrology 13 172-184

Sharpe RM, Millar M and McKinnell C (1993) Relative roles of testosterone and the germ cell complement in determining stage-dependent changes in total protein secretion by isolated rat seminiferous tubules International journal of Andrology 16 71-81 